\title{
Indian Call Centres and Business Process Outsourcing: a Study in Union Formation
}

Phil Taylor, Premilla D’Cruz, Ernesto Noronha, Dora Scholarios

\begin{abstract}
In this exploratory study of union formation in the Indian call centre/business process outsourcing sector, the authors draw upon evidence from the first detailed survey of members of the recently formed UNITES, and from extensive interviews. This paper engages with mobilisation theory and analyses of trade union formation.
\end{abstract}




\section{Introduction}

Given the central concerns of New Technology, Work and Employment it is entirely appropriate that the journal has hosted extensive discussion of the call centre. Understandably, most contributions consider issues of management control and surveillance generated by the information and communication technologies that are integral to the call centre's functioning (e.g. Bain et al, 2002; Barnes, 2007; Russell, 2007). As part of a vigorous literature in labour and management studies, these contributions have deepened our knowledge of the 'internal workings' of the call centre (Glucksmann, 2004) although, arguably, at the expense of embedding it in wider political, economic and spatial contexts (Ellis and Taylor, 2006). Consequently, several significant sub-plots remain undeveloped within the call centre narrative. Coverage of trade union developments whether the extent of recognition, identification of bargaining agendas, organising the unorganised or worker attitudes to representation is more limited than might be expected, despite notable contributions (e.g. Bain et al, 2004; Bain and Taylor, 2000; 2002; Fisher, 2004; Heery et al, 2000; Taylor and Bain, 2001; 2003). In addition, call centre relocation from the global north to the global south is belatedly receiving the attention it deserves. Recent studies focus on the transnational, relocated labour process (Ramesh 2005; Taylor and Bain, 2005; 2006a), on HRM (Batt et al 2005; Budhwar et al 2006) and on cultural identity (Cohen and El-Sawad 2007; McMillin, 2006; Mirchandani 2004; Poster 2007).

Here we weave together these two aspects - trade unionism and offshoring - through an investigation of employee attitudes to collective organisation in India. The study is foregrounded by the formation in September 2005 of UNITES Pro (Union of Information Technology Enabled Services Professionals), which aims to organise employees in the broader Business Process Outsourcing (BPO) sector ${ }^{1}$. Both informed commentary in the influential Indian journal Economic and Political Weekly and initial academic contributions have laid the basis for meaningful debate on the potential for union organising. The dominant discourse stresses the impossibility of the task facing unions. Sandhu asserts,

Call centre employees do not want to be part of trade unions because they associate the latter with 'blue-collar workers' and not with their perceived upward mobility. Also, their work schedules and the highly modernised self-contained work islands they inhabit encourage them to think of unions as unnecessary (2006: 4319).

\footnotetext{
${ }^{1}$ Although BPO encompasses diverse non-customer facing, back-office processes, the focus on the call centre is justified since 'voice' comprises around $65 \%$ of services provided.
} 
Noronha and D’Cruz (2006), following Peetz (2002) emphasise the exclusivist (explicitly antiunion) and inclusivist strategies pursued by employers. High salaries, a powerful professional identity and sophisticated 'subsitutionist' HRM strategies combine to 'impede the development of any kind of collective' (Noronha and D'Cruz 2006: 2120). Reprising earlier Foucauldian arguments (e.g. Knights and McCabe, 1998) that eschewed the possibility of collective resistance, strategies of 'corporate culturalism' aimed at winning employees' 'hearts and minds' ostensibly keep unions at bay (D'Cruz and Noronha 2006). According to this perspective, the industry's middle-class graduate employees so eagerly embrace the employment opportunities presented by the growth of Indian BPO, that they identify uncritically with corporate success and subordinate themselves entirely to managerial demands. The outcome is the construction a 'productively docile' workforce (Ramesh, 2005).

A principal objective of this paper is to interrogate this categorical claim that organising efforts in Indian call centres will necessarily fail and that, by implication, the specific UNITES initiative is stillborn. Drawing on a sample of the unionised constituency within the Indian workforce, we examine the factors prompting employees to join UNITES, their perceptions of HRM departments as substitutes for independent employee representation, and their assessment of the difficulties facing UNITES. We conclude by discussing the importance of workplace activists as union builders.

The findings are prefaced by an engagement with the existing literature on call centre trade unionism. We fully acknowledge that the issues of concern to Indian employees cannot be anticipated simply by reference to the UK experience; nor can union agendas appropriate to developed countries be mechanically transplanted to the global south (Taylor and Bain, 2008: 148). Wider consideration must be accorded to the place that Indian call centres occupy in the emerging global service supply chain and to the position of its workforce in a new international division of service labour (Taylor and Bain, 2005). This necessarily involves focusing upon the technologically-enabled spatial characteristics of the call centre, an undertaking that prompts reflection on developments in labour geography (Rainnie et al, 2007) and on the dynamics of offshoring. While knowledge of the potential for trade unionism in Indian call centres is intrinsically valuable, this study's wider significance lies in the fact that little is known of organising workers in the 'offshored' industries within developing economies (Castree et al 2004: 210; Kelley 2002: 396). Arguably this lacuna reflects actual weaknesses in trade union implantation. Thus, the evidence, insofar as it reveals developments favourable to collective 
organisation, may contain lessons for organising in BPO in other geographies and may even have implications for trade unionism beyond the sector.

\section{Call Centres and Trade Unionism}

Given the complete absence until recently of a union presence in Indian call centres and in the wider BPO sector, existing studies embedding UK call centres in unionised settings (e.g. Fisher, 2004) will by definition have limited purchase. To the extent that union recognition in UK call centres developed it was achieved principally through extending existing company-wide arrangements to newly established call centres (Bain and Taylor, 2002). Since Indian BPO quite obviously is not the outgrowth of indigenous unionised companies, but rather the creation of the offshoring decisions of companies in the developed economies, this route to unionisation has been prohibited. Further where offshoring has been undertaken by firms which do recognise unions in their 'home' geographies, they have refused to extend these rights to their remote operations. This most obviously applies to UK companies in the finance sector (e.g. Prudential, Royal and Sun Alliance, Lloyds/TSB), telecommunication (British Telecom) and other sectors, but far less to US companies in which union recognition is very limited.

Despite the different circumstances of labour vis-a-vis their respective positions in the transnational servicing chains (Taylor and Bain, 2008), certain important generic themes emerge. Employer opposition to unions is pronounced in the outsourced sub-sector where minimising (particularly staff) costs and maximising labour flexibilities are central to the subcontracted proposition. These facts, of anti-unionism and extensive non-recognition by outsourcers, surely have relevance for organising in Indian BPO, where third-party provision comprises a significant element. Researchers also acknowledge the recruitment difficulties stemming from certain organisational and spatial characteristics of the call centre. These include the intensive and individualistic nature of task performance and variable shift patterns which constrain employees' ability to interact with colleagues (Bain and Taylor, 2002). Combined with the long-recognised impact of high attrition these conditions militate against attempts to develop links between actual and potential members and to establish workplace organisation. Location in business parks or multi-tenanted offices compounds access problems, particularly where employers are hostile (Barnes, 2007).

Conversely, some have found agents in non-union environments displaying attitudinal and ideological characteristics that are at least compatible with collectivisation and unionisation. In one study (Bain et al, 2004) majorities expressed support for independent employee representation and 
the right to take industrial action, views combined with widespread dissatisfaction with management. Others demonstrate that articulating the concerns and interests of employees is crucial to effective member representation in unionised settings and to successful organisation amongst non-unionised workers. In addition to conventional pay and conditions agendas, this means prioritising the 'point of production' issues that arise from the call centre labour process, such as targets, breaks, pace and intensity of work and oppressive supervision (Taylor and Bain, 2001). Unions have certainly adopted diverse and often imaginative tactics from outside and within to grow a membership base ${ }^{2}$, recognising the limitations of approaches reliant upon the $a$ priori selection of the salient issues.

Yet, beyond a handful of studies (Heery et al, 2000; Simms, 2007; Taylor and Bain, 2003a) we know little about the dynamics of union formation in unorganised call centres. Both Heery et al's (2000) and Taylor and Bain's (2003a) studies of TypeTalk and Excell respectively examine the application of the organising model, while the latter utilises mobilisation theory (Kelly, 1998). In analysing the processes by which individual discontents harden into collective grievances, for which management is attributed as being responsible, and how workers can became collective actors, mobilisation theory provides one necessary conceptual framework. The emphasis placed upon 'micromobilisation contexts' (McAdam, 1988, 134-5), the group settings in which processes of collective attribution are combined with rudimentary organisation to produce mobilisation for collective action, are important for understanding how a union presence becomes established in non-union call centres.

The question of leadership is germane, not least because of its centrality to the processes by which individual workers are transformed into collective actors (Kelly, 1998) and to building elementary organisation. Taylor and Bain's (2003a) account of unionisation in a hostile environment is positively instructive, for the workplace activists who built the union had no previous union history, assuming leadership roles only in the course of challenging perceived injustices. Yet, this case may be more exceptional than typical. Recent evidence by Gall (2005) and Simms (2007) indicates weaknesses amongst workplace activists in terms of their skills or confidence to represent members (individually or collectively) without considerable support from full-time officers and/or organisers and the commitment of substantial resources. Further, while the daily experience of regimented work may create a deep well of discontent, exit and turnover rather than a commitment to developing collective organisation may be employee responses. Discontent does not necessarily result in, far less guarantee, unionisation. Even in favourable conditions of

\footnotetext{
${ }^{2}$ Those adopted in hostile environments include health and safety surveys, representing employees in disciplinaries and challenging the indignities inflicted on workers by supervisors or managers.
} 
widespread employee grievances, antipathy towards management and extensive pro-union attitudes, the missing behavioural and institutional constructs, notably workplace leaders, are profoundly important (Bain et al, 2004). Given the very recent history of UNITES and the absence of union traditions within BPO, limitations in respect of self-reliant workplace leadership and appropriate union resources and structures may be of greater significance in the Indian context.

\section{Offshoring to India}

The spatial relocation of business services from the developed countries of the 'global north' to the developing countries of the 'global south' now extends far beyond earlier experimental phases (Huws and Flecker 2004). Indeed, the remote delivery of services to low cost destinations has become a core element in corporate re-structuring and re-engineering programmes. Offshoring to India originated in the mid-1990s when American Express, British Airways and GE Capital established customer support operations and transaction processing centres (Nasscom, 2002), following India having established itself as a viable destination for software development (Arora et al, 2001). The first voice centres were established by GE in the late-1990s. The motivating factor was undoubtedly the promise of substantial cost savings in circumstances of relatively tight US labour markets. GE's estimated annual savings of $\$ 340$ million from its Indian operations (Nasscom-McKinsey, 2002), provided a massive spur to relocation, particularly in the circumstances of the dotcom crash and the imperative to cut operating costs. Self-evidently the political economy of business service and call centre offshoring involves corporate cost reduction and profit maximisation strategies driven by shareholder pressure within the broader contexts of trade liberalisation and de-regulation.

Technological developments underpin global relocation. Digitilsation and huge increases in optical fibre capacity transformed the ability to store and transmit data (Miozzo and Soete 2001), ultimately enabling India to become the 'world's back-office'. We should recall that the integrated computer and telephonic technologies that define the call centre removed the need for servicing sites to be located in close proximity to customers (Ellis and Taylor 2006). Their increasing overseas migration in the current decade arguably represents an extension, albeit dramatically and at a transnational scale, of the same cost-saving, profit-maximising spatial, economic and organisational dynamics underlying their initial (re-)location within the developed geographies (Taylor and Bain, 2007).

While the earliest offshoring involved 'in-house' or captive operations, which the evidence from India suggests has always formed the largest part of Indian BPO (e.g. GE Capital, Dell, Hewlett 
Packard, AOL), the complexion of the industry changed in the new millennium. Indian third-party operators such as EXL, ICICI OneSource (now First Source), 24/7, Mphasis (now acquired by EDS) and Transworks increasingly attracted work from the US and then later from the UK. Although not involved in the earliest phases US based multinational corporations increasingly penetrated the Indian BPO space and accelerated the pace of offshoring. These MNCs comprise global general business service providers such as IBM or EDS, specialists in a particular domain such as Hewitt (human resources) and consulting firms such as Accenture $^{3}$ which act simultaneously as advocates for offshoring and as suppliers. Latterly, there has been the rapid growth of domestic segment (Nasscom 2007b: 79). In short, the Indian BPO sector as it developed was far from homogenous in its organisational structure.

Constraints of space prevent a nuanced analysis of the political, economic, technological, organisational, geographical, linguistic, labour market and cultural factors (Dossani and Kenney, 2006; Taylor and Bain 2003a; 2005; 2006b) that make offshoring a complex and contradictory phenomenon. However, cost savings, estimated at 40-50\% (Nasscom, 2006), have been fundamental. Undeniably the most significant element is India's outstanding country asset, the low costs of its English-speaking, graduate workforce. Despite some erosion of the labour cost advantage, so considerable is the differential ${ }^{4}$ between India and the advanced economies that it remains the pre-eminent offshored destination within a rapidly expanding global landscape. India accounted for an estimated 46\% of global BPO in 2005 (Nasscom-McKinsey, 2005) and now employs 704,000 (Nasscom, 2008). Notwithstanding these powerful economic forces driving offshoring, there are manifold constraints, not least in terms of the cultural and linguistic difference, problems of control and regulatory issues which serve to inhibit migration.

As argued fully elsewhere (Taylor and Bain, 2005; 2006), the evidence of the scale and nature of offshoring from the UK to India contradicts the grand claims of the hyperglobalisers (e.g. Cairncross, 1997) regarding the 'death of distance' and the removal of all constraints on the global movement of capital, technology and knowledge. The services that have been migrated to India have tended to be the most transactional and standardised, generally lacking in complexity (Dossani and Kenney, 2003) even though there has been some modest growth in the higher skills that fall under the umbrella of KPO (Knowledge Process Outsourcing).

\footnotetext{
${ }^{3}$ By late 2007 it was estimated that Accenture employed 35,000 more than the size of its US workforce (Information Week, 5 November 2007)

${ }^{4}$ For several years industry body Nasscom has quoted the overall wage differential as between $70-80 \%$ for 'offshorable processes' (Nasscom, 2003: 65).
} 
The circumstances surrounding the rapid creation of this workforce, the emerging structure of the industry and the nature of work organisation all have implications for unionising attempts. The pace of expansion has led to significant labour shortages, notably of higher-end linguistic skills (Budhwar et al, 2006), with the industry predicting a shortfall of 500,000 employees by 2010 (Nasscom-McKinsey 2005: 17). Attrition far surpasses 'official' annual rates of 30-40\% (Nasscom 2006) and exceeds $100 \%$ in certain companies, locations and on particular processes (Taylor and Bain 2006b: 84-100). While the 'push' of working conditions contributes to turnover, of greater significance are 'pull' factors, whereby employees move between facilities for better pay and conditions. Self-evidently, strong labour market conditions have implications for union organising. While high demand places labour potentially in a strong bargaining position, contradictorily, high attrition encourages employees to pursue individualised solutions (changing employer, promotion) at the expense of engaging in a collective undertaking.

The very heterogeneity of the industry might create difficulties for union organising attempts. Clearly in terms of international facing centres the variation in the contractual relationships between the company doing the offshoring and the Indian supplier is a pertinent issue, spanning the spectrum between in-house captive and sub-contracted third party outsourcing, but including forms of partnerships and joint venture (Chakrabarty, 2006). Differentiation in other aspects carries additional implications for organising. There is the question of scale. While prominent 'captives' and third-party suppliers are large employers ${ }^{5}$ and their facilities accommodate several thousand employees, there remains a plethora of SMEs, many in the domestic sub-sector, which conducting niche activities. Batt et al (2005: 7) showed that international-facing call centres were seven times larger than 'domestics'. There are the obvious distinctions in forms of work, with 'voice' still accounting for as much as $60 \%$ of employment and back-office activities $40 \%$ (Taylor and Bain 2006b). Differentiation exists too in the sectoral basis of the workflows, with the financial services sector perhaps accounting for around $50 \%$ of business volumes, with telecommunications, utilities, retailing, IT, hospitality and travel important areas of 'vertical' activity.

Work timings vary markedly since much back-office work is conducted during daytime hours while voice processes are synchronised to customers' times across the different English-speaking geographies ${ }^{6}$ leading to extensive night-time working. The resulting multiplicity of shift patterns further fragments the construction of BPO work as a unified experience. Pay and rewards too are distributed unevenly across the 'sector'. Surveys show that remuneration tends to be higher for

\footnotetext{
${ }^{5}$ e.g. Genpact employs around 23,000 in India, HSBC 17,000, IBM-Daksh 25,000, Wipro 20,000+.

${ }^{6}$ North America accounts for c70\% of Indian BPO's business and Europe (principally UK) c20\%.
} 
back-office employees than for voice-based agents (Nasscom 2007: 148) and, it appears 'captives' and MNCs tend to pay more than Indian third-parties and considerably more than domestics.

Notwithstanding these important differences certain commonalities are identified in working conditions and employees' experiences. For 'captives', MNCs and international facing third-party centres, the nature of work derives from the place that India occupies in global servicing chains. Accordingly, work organisation might constitutes an intensive form of the mass production model (Taylor and Bain 2005: 269), a result of what might be termed 'Taylorism through export'. Recent evidence (Taylor and Bain 2006b: 46-71) confirms that Indian BPO generally, whether captive or third-party, call centre or non-customer facing, tends to deliver services of lower complexity. Tight monitoring, surveillance and manifold quantitative and qualitative controls are implemented which minimise employee discretion. For example, Batt et al (2005) found $76 \%$ of managers saying employees had little or no discretion over work procedures.

Although Ramesh's (2005) 'cyber coolie' metaphor may be overdrawn many agents describe work as a pressurised and frequently stressful experience. To repeat, it is not being argued that highlypressurised working conditions lead automatically to a propensity to collectivise. As D'Cruz and Noronha (2006) contend, BPO professionals imbued with a strong customer servicing ethos may internalise these pressures. Nevertheless, from the perspective of unionising possibilities the contradiction between the expectation, encouraged by employers, of a stimulating job and rewarding career and the actuality of performing industrialised white-collar work may be an important underlying factor (Mirchandani, 2004).

Distinctive characteristics of Indian BPO exacerbate pressures; nocturnal call-handling for overseas customers, long commuting times, extended shifts, unpaid overtime. Agents confirm prevalent symptoms of work-related ill-health and disruptions to work-life balance and family life, which may impact most upon women. There are complex issues of identity construction, as Indians navigate the tensions between their culture and the requirements of service provision for western customers, including such practices as locational masking, adopting pseudonyms and accent neutralisation. Identity issues have preoccupied many researchers (Cohen and El-Sawad 2007; Mirchandani 2004; McMilan 2006). Agents are not simply more intensely exploited units of capital, but rather are active economic and cultural participants who, in constructing their own meanings of work, may develop forms of 'objection' or 'resistance', rather than 'assimilation' or 'accommodation' (Poster 2007). 
Finally, researchers have identified a 'democratic deficit'. There is evidence that customary Indian hierarchical work cultures have been transposed to BPO, and not merely to its third-party and domestic segments (Taylor and Bain 2006a). Employees report managerial and supervisory arbitrariness, including disciplinaries and even dismissals for little reason. Top-down methods dominate staff communications systems (Nasscom 2003) and employee involvement practices are geared solely to productivity and quality improvements, and not to giving employees a voice in decision-making (Batt et al 2005: 17). Finally, underscoring this deficit, although many UK offshoring companies recognise trade unions, they do not extend this right to their Indian operations (Bain and Taylor, 2008).

\section{Unites and Trades Unionism in India}

To counter the general democratic deficit within Indian BPO, UNITES was formed in September 2005 following an initiative by global union federation UNI (Union Network International) through its Indian Liaison Committee, preparatory organising efforts under the provisionally named Centre for Business Outsourcing Professionals (CBPOP) and an organisational break from the Information Technology Professionals Forum (ITPF) which orientates on software/IT professionals (Hirschfeld 2005). UNITES was therefore the first explicit attempt to give BPO employees an independent voice.

Arguably, the broader context within which UNITES was proposing to operate was less than favourable. While trade unions certainly have legal status under the Trade Union Act of 1926, historically, trade unionism has been confined to a relatively small, formal or organised segment (Sheth, 1996). A significant characteristic of the Indian movement has been differentiation, if not fragmentation, along political lines so that practically every party has had its own trade union wing. As illustrative of this legacy, in 1989 the government's verification exercise identified eight major union federations besides a number of small independent unions, which largely remained the case in 2002 (GOI 2002) $)^{7}$. Due to a complex of historical, political and economic factors trade union affiliation to political parties at national and regional levels has manifested itself in trade union rivalry (Datta Chaudhuri 1996).

Union activity, particularly in terms of an ability to call 'legal' strikes, has also been circumscribed through regulation in the form of the Industrial Disputes Act of 1947, which instituted mandatory

\footnotetext{
${ }^{7}$ The largest of these federations in order are the BMS (Bharathiya Mazdoor Sangha (BMS), INTUC (Indian National Trade Union Congress) affiliated to the Congress Party, HMS (Hind Mazdoor Sabha), CITU (Centre of Indian Trade Unions) affiliated to the Communist Party of India - Marxist and AITUC (All India Trade Union Congress, affiliated to the Communist Party. (http://www.labourfile.org/superAdmin/Document/113/table\%201.pdf)
} 
conciliation and arbitration procedures (Kennedy 1966). The creation of these institutional arrangements enhanced the influence of the Congress Party controlled INTUC, leading to incorporation and further state mediation of the employment relationship (Chaterjee 1980). Compounding division and weakness was the emergence from the 1970s of more 'self-interested' unionism directed by more bureaucratic businessmen-leaders and which was based upon groups of more prosperous workers (Bhattacharjee 2001; Sheth 1993). This self-interested unionism eschewed the political unionism and external leadership characteristic of unions in the past (Kuruvilla et al 2002) and led to wider disillusionment with the union movement (Sheth 1993).

Economic liberalisation from 1990 brought a sea change in industrial relations practices, with government and employers embarking on programmes of downsizing, flexibilisation, subcontracting and the transfer of jobs from 'bargainable' to 'non-bargainable' categories (Noronha 1996). These pro-employer policies reflected the increased schism between the unions and their traditional allies, the political parties, as the former opposed economic liberalisation, while the latter supported it (Kuruvilla et al 2002). The fall out from these policies has resulted in the decline of employment growth in the organised sector (both public and private) between 1994 and 2005 and the unorganised component of the total workforce grew from 91.2 per cent in 19992000 to 92.4 per cent in 2004-5 (GOI 2008a; b).

Despite these weaknesses trade unions have demonstrated strong traditions in the telecomunications, banking and insurance (Kuruvilla et al 2003), in part a reflection of the legacy of state ownership. These sectors might be regarded as being closest to the business activities of contact centres and BPO. However, constrained by their preoccupation with organisation level institutional arrangements, unions displayed a reluctance to organise the new BPO workforce. Interviews conducted with national officers of the telecommunications and banking unions at the time India's BPO industry was beginning to undergo dramatic expansion revealed their reluctance to engage in organising efforts, believing that BPO represented very difficult territory for trade unions. At the same time, any organising effort would have to confront employer hostility by Indian third party employers, as evidenced by Ramesh (2005) and Cooke (2005), and the opposition of multinationals such as IBM and EDS which have industrial relations' histories demonstrating deep antipathy to trade unionism. Nasscom has publicly denied that unions should play a role in BPO ( http://rediff.com/money/2005/oct/17bpo.htm).

Consequently, UNITES' founders consciously recognised the need to take account of employer hostility to trade unionism and of employees' powerful sense of professional identity. A key 
element in UNITES' approach was to promote itself as 'a community of professionals', providing information, advice and training services for its career-minded members.

Overcoming bureaucratic obstacles UNITES secured legal status through the Labour Commission in Karnataka and gained 'Provisional Affiliation' to INTUC. At the time of the research it had organising centres and claimed viable 'chapters' in Bangalore, Hyderabad, New Delhi, Chennai, Mumbai and Kochi (UNITES, 2006). The distinction between fully paid-up members (600 rupees p.a. ${ }^{8}$ ) and those paying an initial registration (100 rupees) is important. Officers report a willingness to pay the initial fee but some difficulty in translating 'sign-ups' into full membership. Thus, it is helpful to think of UNITES membership as stratified, with a committed core and a looser periphery, surrounded again by non-members who comprise a broader, interested constituency. Accordingly, although 7,000 recruits were claimed by late-2006, the General Secretary estimated full membership at 700-1,000 (Interview 19.11.06).

\section{Research Questions}

Informed by this discussion, five specific research questions drive the study. First, what do the characteristics of UNITES' membership tell us about the organisation's success - or otherwise - in establishing a presence in Indian BPO? Second, what are the reasons why BPO employees have joined, or may join, UNITES? Third, according to UNITES' members, to what extent is there validity in the claim that companies' HRM departments can substitute for independent employee representation? Fourth, what do members identify as the principal obstacles hindering UNITES' recruitment attempts? Fifth, what are the processes by which members have been recruited?

\section{Research Methods}

Questionnaires were targeted at UNITES' members working in domestic, third-party, and captive operations (April-July 2007). Access to membership databases was permitted by UNITES' officers with whom the authors had developed collaborative relationships since 2005. Researchers completed the questionnaires as face-to-face interviews with as many members as possible in each locale. This produced 879 completed questionnaires from Bangalore (30\%), Chennai (17\%), Hyderabad (16\%), Kochin (16\%), Mumbai (14\%) and New Delhi (8\%) which, we are confident, reflects UNITES' active membership. The questionnaire, based on existing call centre surveys and new questions designed for the Indian BPO context, was structured as follows.

\footnotetext{
${ }^{8}$ At the time of the research there were around 75 rupees to the $£$ sterling.
} 
Demographic profile: Questions included: company type, job title, the extent of voice/ back-office work, type of calls handled, working hours/shifts, age, gender, contractual status, tenure, and orientation to present job and career.

Reasons for joining: Respondents rated the importance of 13 items covering individual services (e.g. providing training to enhance knowledge/skills) and more traditional collectivist reasons (e.g. belief in unions) (Waddington and Whitston, 1997). Exploratory factor analysis indicated four types of reasons: traditional collectivist, collectivist/social, instrumental (individualist/collective), and careerist/instrumental (Table 2). ${ }^{9}$ Respondents also rated 15 factors identified from previous Indian call centre research (Table 3).

Role of HR: A single question asked whether members believed HR removed the need for trade unions. If respondents had turned to HR to solve a specific problem, they were asked to rate HR's success in three respects: being available, listening/understanding, and actions taken. Those who had not turned to HR were asked to indicate how they had dealt with problems (Table 4).

Obstacles to increasing membership: Respondents rated the importance of 14 items representing barriers to union growth drawing from d'Cruz and Noronha (2006) and Taylor and Bain (2006a) (Table 5).

Recruitment: Respondents were asked to indicate the sources of information which made them aware of UNITES and the procedure by which they joined. The options captured three types of recruitment (Waddington and Whitston, 1997) - direct union approaches, informal methods (e.g. through friends) and efforts initiated by the workplace, in particular managers - and were based on evidence that unions are often unable to make contact with workers (Green, 1990). Members assessed the ease of joining and what might have made joining easier.

The questionnaire was piloted in February 2007 in Chennai. The research team conducted supplementary semi-structured interviews in Chennai, Delhi, Hyderabad and Bangalore, which enabled deeper exploration of members' experiences. A cross-section of members by gender and company-type led to 45 interviews, each lasting approximately one hour. All interviews were taped and transcribed.

\section{UNITES Membership}

Given the thoroughness of data collection in each locale, we can reasonably infer that completed questionnaires accurately represent UNITES' active membership. The majority of respondents (70\%) and correspondingly UNITES members, are in domestic operations, with $22 \%$ in captives and $8 \%$ in third-parties (Table 1). This is an important finding, revealing UNITES' relatively

\footnotetext{
${ }^{9}$ Further statistical analysis not included in this paper is available by request from the authors.
} 
insignificant presence in international centres. Greater implantation in domestic centres reflects UNITES' success in having negotiated collective agreements with five SMEs. While most (69\%) had joined UNITES in the last year, this figure rose to $80 \%$ for domestics, indicating a loss of recruitment impetus in international-facing centres. Of specific concern to UNITES' leadership must be the fact that only $28 \%$ of members in third-parties had joined within the last year.

Positively, to the limited extent that UNITES has grown, it has succeeded in recruiting equally from both genders. Membership also reflects the strikingly youthful workforce; the mean age of surveyed members was 24 . That most respondents were employed full-time is also consistent with data on Indian BPO. Batt et al (2005: 9) found that 99\% of international agents were full-time. More outstanding are the statistics on working hours. The monthly mean of 216 hours demonstrates the prevalence in Indian BPO of a long hours' culture, most pronounced in captives and domestic centres. Average length of service was $1 \frac{1}{2}$ years, although lower in domestic companies at over one year. Given what is known about attrition, this may indicate that UNITES is more likely to attract employees with lengthier tenure.

The evidence on career orientation provides fascinating insight into the intentions of this cohort. Overall, only one-in-four believed that their current job was one that they would stay in or was part of their career advancement. A majority in domestics believed that their current job was part of a career that would take them to other BPO companies, compared to $30 \%$ in captives and $22 \%$ in third-parties. Interview data reinforces the supposition that both members and their nonunionised colleagues in domestic centres see their jobs as a stepping-stone to employment in better paying and higher status international-facing companies. Evidently, though, there are multiple career motives amongst UNITES members. While a willingness to move employer in order to better oneself was reported, several interviewees expressed their desire to build a career in their 'dream job'. A call centre agent in a Bangalore-based captive effectively expressed the duality of his colleagues' orientations.

Every second company is willing to pay you very well irrespective of your experience. If things don't work out well in one company they don't care, they can go elsewhere. Having said that there are lots of people who really don't like doing this. Security of job is also important for them. It's a kind of mixture at times.

Mindful of this contradiction UNITES has responded pragmatically. Inter-company migration certainly provides opportunities for UNITES to establish toeholds in areas where it has no presence. The General Secretary (Interview 4.08.07) emphasised the importance of recruiting 
members from UNITES' domestic pockets and then sustaining individuals' membership as they become dispersed throughout BPO. However, UNITES has also developed agendas which emphasise that companies must develop career pathways for their employees in captives and thirdparties. Concomitantly, more stable workforces are seen as essential if UNITES is to put down firmer roots.

\section{Reasons for Joining}

Table 1

While employees join UNITES for multiple reasons, the most frequently cited were what we have called instrumental (individualist/collectivist) - improving pay and conditions and providing information/advice about rights. This category encompasses explicitly individualistic and collective motivations. Pay and conditions were identified by around three-quarters of respondents (Table 2) with the notable exception of those in Indian third-parties. Interview evidence reveals several instances where UNITES had intervened externally and internally on behalf of employees over pay-related grievances (the withholding of pay/bonuses, unpaid overtime, underpaying). Others expressed the view that, while UNITES could not impact pay rates in the short-term, its future ability to do so influenced decisions to join. Clearly for members in domestics who benefit from the collective agreements their responses reflect a more immediate explicitly collectivist reality.

Two-thirds overall also cited UNITES' ability to provide information or advice about rights, reasons expanded upon in interviews.

I think UNITES is very useful for people who are trying to enter the BPO industry... when they have nowhere to go and they feel they do not have that voice to speak up, and when they feel that there is a lot of prejudice and...so many problems. (BPO agent, captive, Bangalore)

In the early days there was nowhere for an employee to go in terms of whatever issues claims, insurance - they might have. Here UNITES is calling people and saying if there is a problem [with your rights] we will represent and help you. (Voice agent, domestic Bangalore)

Careerist reasons, such as UNITES' provision of training, were cited by approximately one-third, rising to around half for members in captives. This finding resonates with arguments stressing the importance of employees' professionalism and aspirant careerism. Interestingly, these reasons 
were also cited more often by members who did not consider their current jobs part of a longerterm career, either in the company or BPO. Those who already considered their jobs part of a career within BPO were least likely to identify careerist reasons.

The data provides evidence of more traditional collectivist orientations. One-third overall, and $62 \%$ in captives, cited their belief in trade unions as a reason for joining. This was also the second most popular reason for those who saw their job as part of a wider BPO career. These findings undermine the argument that because of their professional aspirations individual employees will inevitably reject trade unionism. Although a belief in trade unionism was considerably weaker in third-parties, collective impulses were still discernible. Over $40 \%$ believed in independent representation and were attracted by attitudes shared with other members. Collectivist reasons with a social or informational function (information about housing, helping the community) were cited most often by those in captives and those with greater than one year tenure. In third-parties, the majority reason for joining was the support provided for individual problems and the presence of UNITES members at work.

In sum, although most members joined primarily for instrumental reasons related to pay, conditions and information about rights, the evidence suggests that these are as much quasicollectivist as individualist in intent. Of considerable interest is the existence of more traditional collectivist beliefs and UNITES' ability to support individuals with problems at work.

\section{Table 2}

When asked to reflect upon the working conditions prompting their non-member colleagues to join, the most significant issue was working times, cited by $65 \%$ overall as 'very important' and receiving the greatest agreement across all groups (Table 3). This has several dimensions including shift-length, night-time working, effects on well-being and travel-to-work time. Health and safety issues emerge as second most likely to prompt non-members to join confirming other evidence (Taylor and Bain, 2006a;b; Ramesh, 2005), which has led the Minister of Health to prepare

guidelines for the industry (http://sify.com/news_info/news/othernews/fullstory.php?id=14538595).

Safety and security, which received an importance ratio of $93.2 \%$, is an issue of major significance in the Indian context. Indeed, UNITES' first tranche of recruits followed its active campaigning for better regulation of transportation after the murder in December 2005 of a women working nightshift for Hewlett Packard in Bangalore by a man purporting to be her driver (Taylor and Bain, 2008). Exposing industry negligence, the longer-term resonance of the Prathibha Srikanth Murthy 
case is seen in these findings, confirming UNITES' potential ability to promote fundamental employee rights.

Given industry growth, it is notable that $62 \%$ consider job insecurity to be very important. Interviews indicate members' concerns regarding the permanence of job opportunities as company decisions might see India supplanted as an offshored location. Nevertheless, perceptions of insecurity are often rooted in management's treatment of individuals and their sense of vulnerability. This is particularly true in SMEs and domestics. A member from a Bangalore domestic reported,

...certain employees could not do anything except succumbing to the managerial discretion. They have nobody to fall back to rather in the sense somebody they could look for some help and support...once in a while where there are people who seem to be targeted, who absolutely have no rights whatever of any kind. Because they are helpless, they are victimised or probably they have to succumb to the entire thing. Eventually they leave sacrificing the salary.

Respondents consistently identified task-related work pressures and targets, about which call centre employees have long complained. Rated by $40 \%$ and $45 \%$ respectively as 'very important' many believe these are important factors which could be addressed by joining UNITES. Interview evidence provides innumerable illustrations of these essential characteristics of Indian call centre work such as this graphic example.

...daily targets are given because it is a typical call centre. Obviously the call centre is a target concept. At a stretch, a technician is supposed to take at least 50-60 calls, that is typically a Herculean task. Time is money. But there should be something called time for relaxation. Huge call volumes. People are stopped from going for their breaks or their breaks are postponed to a large extent, their brain stops working and they start shouting at customers. Once they find that the person has shouted at the customer, he is thrown out of the job. But they don't address what is the problem or the reason for that action. (Voice agent, Chennai captive)

Demanding supervisors were particularly important for those in domestic companies and those with shorter tenure. Interviews provided further examples of how the supervisor's behaviour may affect more vulnerable workers. 
No time to freshen up. We were not given paper cups. We were not allowed to get it inside also. So no water, three hours continuous talking, without taking a glass of water. We were supposed to be happy with the lunch-break, run, drink water, have lunch, come running back because 30 minutes is over. As the three teams will be having their break, there is hardly any place in the rest-room to rest. You will log-in late at least by 2-3 minutes and you will have red marks. The leader will yell, come to each person and scream. (Chennai domestic)

The team leader should be an example and that has not happened...There is a TL in IBM who used to scream for every small thing at the top of her voice. (Chennai captive).

Some factors did not emerge as prominent. It is worth noting that 'apple polishing' (favouritism) and abusive customers were more important for those in third-parties and those with longer tenure. In addition, for those wishing a career in other BPO companies, the issue of employers making it difficult to leave for another job was identified more consistently. As indicated elsewhere (Taylor and Bain, 2008), the practice of withholding leaving certificates as companies strive to control attrition which prevents employees from moving employer is an important concern in international-facing centres. The infringement of such fundamental rights creates opportunities to tap into central concerns of these 'professional' employees.

Perhaps the most significant finding is that six-in-ten believed the need for employee voice might be very important in prompting employees to join. There was high overall agreement, and most notably amongst those wishing a career in BPO or their present company, challenging the notion that employee representation is wholly inconsistent with a career-oriented workforce.

Table 3

\section{HR as a Substitute for Independent Representation}

Perhaps surprisingly given that this is a survey of union members, $16 \%$ believed that HR removed the need for trade unions (Table 4). Although only a minority this does indicate limited unionateness of a layer of members. More than one in five overall $(22 \%)$ reported that they had turned to HR to solve a problem. While only $10 \%$ of domestic members thought HR obviated the need for unions, this proportion rose to $28 \%$ for captive members and $44 \%$ in third-parties. Furthermore, while only $15 \%$ in domestics had turned to HR to get problems resolved, $32 \%$ in third-parties and $43 \%$ in captives had done so. It seems that HR practice is far less developed in the domestic sub-sector than in captives and third-parties. Those with longer tenure and those 
wanting a company career were more likely to believe that HR may substitute for the union (albeit only one-third) and to have sought the help of HR.

Of the respondents who had turned to HR for problem resolution, those in captives and thirdparties were considerably more positive about HR's ability to respond to employees than those in domestics. Most strikingly, only 7\% of domestic members thought HR had successfully taken action to resolve their problems compared to $40 \%$ in captives and $59 \%$ in third-parties. From another perspective, these figures indicate that a majority of members in captives $(60 \%)$ and a sizable minority in third-parties (41\%) did not have their problems resolved to their satisfaction. For those who did not turn to HR with a problem, the majority either did nothing (55\% captives, $27 \%$ third-parties) or sought support from friends and personal networks (23\% captives, 25\% third-parties). Those who did not consider their job as part of a career preferred the option of seeking another job (45\%).

Thus, it does not follow that sophisticated and effective HR practices necessarily prevail in international-facing centres. Budhwar et al (2005) emphasise limitations in career progression, development and retention policies, while sessions at Nasscom conferences have been dominated by discussions of the need to develop coherent HRM approaches in place of ad hoc 'firefighting' practices which have been preoccupied with continuous recruitment rather than fostering career development (Taylor and Bain 2006b: 76-100). Recalling Legge's (2004) telling critique of HRM, there is often a contradiction between 'rhetoric' and 'reality'. Interviews provide scathing criticism of HR, particularly from this employee with seven years' experience in domestic, third-party and captive centres.

I disagree that HR would solve all the employees' problems. That is absolutely a misconception. They have made it a rule that the employees have to turn to the HR whatever happens. Though the HR department is approachable by employees, they are not too friendly or responsive to respond to employees' concerns... In the last seven years, no HR department has ever helped me with my problems...HR is misguiding the people that they can be approached.

In sum, sufficient evidence exists to question the notion that HR departments and their supposedly increasingly sophisticated policies have the effect of 'rendering unions redundant' (Noronha and d'Cruz 2006: 2118). The general reliance on existing support networks suggests a potential role for UNITES in providing advice or advocacy. 


\section{Perceived Difficulties Facing UNITES}

Issues perceived as most important were companies' opposition to UNITES (57\%), that BPO employees see themselves as professionals (54\%), a fear that companies might terminate someone for joining (54\%), the workforce's youth and inexperience (53\%), high attrition (48\%), that many employees do not believe in trade unions (47\%), and that employees think that joining UNITES would affect their careers (45\%) (Table 5). High attrition received the highest importance ratio, signifying strong agreement about this logistical barrier facing UNITES with respect to the transient nature of the workforce. Also notable are the second, third and fourth highest issues showing strong agreement that UNITES (except in third-parties) faces difficulties because employees regard themselves as professionals, they earn high salaries, and expect promotion.

The survey, then, does provide evidence regarding the effectiveness of 'exclusivist' and 'inclusivist' strategies. 'Inclusivism' certainly appears to present UNITES with obstacles to recruitment, particularly in respect of employees' powerful professional identity. Nevertheless, companies' cultural control strategies seemingly have limited purchase. Only minorities - mostly in captives, third-parties and those with longer tenure - viewed employers' capture of 'hearts and minds' as an important deterrent. There was also little support for the argument that unions would damage the growth of Indian BPO. Companies' overt opposition to UNITES was cited mostly by employees in captives. Interview data delivers powerful insights, notably the testimony of the member who maintained UNITES' website. He reported the frequency with which those contacting UNITES would say, 'Can I join in secret?' or 'I am a member but please do not let it be known', fearful of 'termination' if their membership became known to management.

In cases where there is a person who is courageous and does not bother, [they] will not have to have a particular reason to terminate a person. Being a union member can be one of those reasons. Again, when they sign their contract letter initially, they sign and say they will not be a member of a union. This is another reason why they do not want to say they are a member.

Reprisals were reported not just against union members, but against any employee who raised their voice. A Bangalore call centre agent revealed.

Whenever we go to the smoking zone or elsewhere, when there is a problem, people discuss it. We used to discuss among ourselves how things go on, how to improve things. 
We cannot raise our voices because once we do that there will be a black mark there. That will affect our appraisal and this fear was there in everybody. Normally, we are scapegoats, keep working and get out. If anyone raises his voice, there is trouble for him.

These findings are consistent with previous evidence of employers' anti-unionism. Ramesh (2005: 17) reported firms 'nipping out any sprouts of organising' and Cooke (2005: 6) recounted the sacking of a Wipro-Spectramind employee who protested against having to undertake unpaid work and intimidatory management.

Table 5

\section{Workplace Leadership}

Unexpectedly, given that UNITES 'started from scratch', 'older' members were likely to report friends or relatives in other call centres as a source of information on the organisation. Interview evidence reveals that longer-standing members often heard about UNITES through social or family connections with those who were involved in initiating UNITES. A Chennai-based member reported that her knowledge of UNITES came from her father, a unionised employee of national telecoms company BSNL.

However, established workplace members are easily the most important source of information and recruitment. Consequently, $80 \%$ overall stated that they had been signed up by a UNITES member in their workplace. Making due allowance for differing national contexts, these findings underscore previous observations regarding the key role of workplace leaders both in call centres and in relation to mobilisation theory. That these informal leaders in Indian BPO play the role of embryonic workplace representatives is evidenced by several vignettes from interviews. At a major third-party company in Noida, a UNITES member organised an internal protest when salaries were not paid which led to a significant breakthrough for the union.

A few of the boys had been badly treated by their house owners and were forced to vacate [when they could not pay their rent]. Management said they should borrow money from others, but because they were new to the city they didn't know anybody. Then we decided to go and speak to the management and the reason they gave was that cheques were lost... So we all went back to the training manager who got very angry because he thought this was a kind of union formation and said, 'No point in talking to me, you won't be getting your salaries so you can all go back'. So the boys got even more angry and said 'Let's call the media'. I came in between them and tried to find someone from senior management to speak to. I told the boys we have an organisation, UNITES, which is 
working for us. They started asking, 'What is UNITES?', which is how we started spreading the news about UNITES. We then contacted the UNITES director who advised, 'Don't call the media people because we should sort this out ourselves. Let's be positive, not negative' and we said 'OK, let's all go together and have one voice'. So we all went to the HR Manager, but he was stalling. Then he saw we were all together and he said, 'I will talk to you now'. Then he said, 'Tomorrow you will be getting your cheques'. And the next day they did. This was the first win for UNITES. So a bit later I got the membership forms printed and people joined. We now have 110 GBK people in UNITES because they are knowing about the work we are doing and what our motive is.

Scattered examples exist of emergent leaders recruiting clusters of members through face-to-face discussion, persuasion and a willingness to contest management's decisions and to pursue grievances on behalf of workers.

Recent members reported UNITES' website and leaflets as important for information and recruitment. Other sources, such as newspaper advertisements and articles, emails, radio or television programmes, or specific campaigns were cited by mere handfuls. However, forms of 'remote' contact and individuals taking the initiative themselves to join (on-line, posting forms) are far less significant. Surprisingly, and an issue of some concern, is that only small numbers joined at UNITES meetings. When asked what UNITES could do to improve recruitment, more meetings, a higher profile and greater media coverage were mentioned. Several stressed how successful UNITES had been in its early days in gaining publicity through the Prathibha and BelAir cases, but that declining media coverage had reduced public and colleagues' awareness. Some older activists expressed frustration at this apparent lack of progress.

UNITES now has to unite really and march ahead. Take serious steps and move fast, now it moves slowly. The faster you move, the faster the processes are going to be. This means you start your media campaign, your one-to-one campaign, so they start getting educated, knowing if you have problems in your call centre, please log onto our website or dial this number (Voice agent Hyderabad).

Table 6

\section{Conclusions}

If organising the non-unionised call centre workers in the 'new economy' has proved difficult in the relatively-densely unionised UK, even when employees display the necessary attitudinal and 
ideological characteristics (Bain et al, 2004; Baldry et al, 2007), then the challenges facing UNITES in India appear monumental by comparison. Arrayed against UNITES and its attempt to organise a meaningful presence amongst BPO employees are a host of significant factors, not least that UNITES is essentially starting from scratch with a virgin workforce which lacks collectivist traditions upon which to draw. Evidently, the messages issuing from Nasscom and BPO employers that trade unionism is unwanted and unnecessary in Indian BPO have purchase amongst employees, whose middle-class graduate backgrounds, youth and lack of experience do not predispose them to think in trade union terms. Many do possess a profound sense of professional identity (d'Cruz and Noronha, 2006) and aspire to careers in BPO. High attrition and rapid growth undoubtedly encourage individualistic solutions within a structurally differentiated industry. Moving workplace to secure better pay and/or for promotion, appears possible rather than a less obvious collectivist route through an organisation, UNITES, which scarcely registers on many employees' radar. There is evidence, too, that many members perceive - and may experience companies' combatitive anti-unionism, which contributes to a reluctance to join UNITES or declare membership for fear of reprisals.

Nevertheless, a myopic focus on the 'exclusivist' and 'inclusivist' obstacles may occlude an appreciation of the progress, however limited, that UNITES has made since formation. The fact that employees, however small in numbers, believe that their interests diverge from those of their employers to such an extent that they take the step of joining is surely significant. For this small and fragmented unionised constituency at least there are evident constraints on the efficacy of cultural control strategies. There is not universal support for the view that HR practices 'solve' employees' problems, nor evidence that 'hearts and minds' have been colonised. Of course, a key limitation of this study is the fact that we cannot generalise from these findings to the BPO workforce in toto. What we have captured are the attitudes of employees who have already indicated, through joining UNITES, their belief in the need for some kind of independent representation.

The exploratory nature of this inquiry emerges through the analysis of the reasons given by members for joining UNITES. Evidently multiple motivations are discernible ranging from an ideological commitment - a finding that challenges the dominant discourse that employees are universally antipathetic to trade unionism - to a complex mixture of collectivist, individualist and careerist impulses. Arguably, these seemingly conflicting orientations of UNITES' members are rooted in contradictions within the broader experience of BPO employment, notably the tension between professional self-identity and career aspiration on the one hand and the performance of 
what for most is routinised interactive service or business process work on the other. Consequently, a challenging task for UNITES is how to tap into the professional aspirations of its potential constituency while, simultaneously, acting more like a trade union, albeit one in the making.

Despite these contradictory orientations, UNITES appears to have a constituency far wider than its existing membership. The survey certainly uncovered manifold grievances; from seemingly trivial indignities to heavy-handed supervision, to diverse issues around pay, to a plethora of complaints over work-times, and profound concerns over employee safety. The evidence suggests that employee concerns are widespread in the context of a democratic deficit.

The position occupied by Indian BPO in transnational supply chains has created lean servicing regimes in which cost-cutting imperatives dominate. If anything, Indian employees in voice and business processes are now being driven harder through 'process excellence' measures (NasscomMcKinsey 2005: 126; Nasscom, 2008) to compensate for rising costs. Work intensification is widening the gap between the promise of stimulating professional work and a prestigious career and the reality of tightly-monitored task routines. Despite comparatively attractive salaries, the quotidian experience of demanding work provides an inescapable context and potential source of dissatisfaction.

If the presence of workplace leadership has been central to the limited success in organising nonunionised UK centres (Taylor and Bain, 2003a) and, conversely, if its absence has stymied efforts (Bain et al, 2004; Gall, 2005; Simms, 2007), then these are of greater salience in Indian BPO. The data provides fascinating glimpses of how embryonic leaders in the distinctive Indian 'micromobilisation contexts' (McAdam, 1988) have keyed into colleagues' discontents, articulated their concerns, sought redress with management and, in the process, have recruited members. Yet these are limited cases. The principal immediate challenge, to paraphrase Marx, is the primitive accumulation of leaders capable of developing self-reliant clusters within workplaces, across companies and in the urban centres of BPO activity. If the evidence here contributes to mobilisation theory it is to underscore the significance of the role played by workplace leaders in getting collective organisation established in the first place. In the context of India, though, this leadership appears as fragile, precarious and dependent upon considerable external support.

A major problem for UNITES in developing these workplace leaders is not just their immaturity and that of their, but severe financial and resource constraints. At best, UNITES has upon one key officer in each major metropolitan centre. It is difficult to see how, without the necessary 
institutional framework that can only come with dedicated teams of full-time organisers in the respective locales, UNITES can provide support for its key resource of workplace leaders and can build stable membership bases ${ }^{10}$.

It should be emphasised that sections of the Indian BPO industry are not hermetically sealed. Particularly as far as captives are concerned, the actions and interventions of unions in the global north and of international federations can exercise an influence. Where recognition exists in developed countries attempts can be made to extend arrangements to India either directly or through global framework agreements. At a minimum, UNITES can benefit from international union support, information exchanges and reciprocal visits ${ }^{11}$. As argued elsewhere (Taylor and Bain 2008), solidaristic actions taken by unions in the UK and internationally at this early stage in the Indian industry's development can have a major impact in this 'entirely new frontier for organising trade unions' (Ofresno et al, 2007: 552).

\section{References}

Arora, A., Arunachalam, V.S., Asundi, J. and Fernandes, R. (2001) 'The Indian Software Industry', Research Policy, 30.8: 1267-1287

Bain, P. and Taylor, P. (2000) 'Entrapped by the "Electronic Panopticon"? Worker resistance in the call centre', New Technology, Work and Employment, 15.1:2-18

Bain, P. and Taylor, P. (2002) 'Ringing the changes? Union recognition and organisation in call centres in the UK finance sector', Industrial Relations Journal, 33.3:246-261

Bain, P. and Taylor, P. (2008) 'No passage to India? The initial responses of UK unions to the migration of call centre jobs', Industrial Relations Journal, 39.

Bain, P., Taylor, P., Gilbert, K. and Gall, G. (2004) Failing to organise - or organising to fail? Challenge, opportunity and the limitations of union policy in four call centres', in G. Healy, E. Heery, P. Taylor and W. Brown (eds.) The Future of Worker Representation, Basingstoke: Palgrave: 62-81

\footnotetext{
${ }^{10}$ Breaking out of its present concentration in domestic SMEs and gaining a meaningful presence in the internationalfacing captives and third-party operations remains is a major immediate challenge.

${ }^{11}$ A delegation from UNITES addressed the UK union UNITE's finance sector conference in June 2008 and then met with union reps in several workplaces.
} 
Baldry, C., Bain, P., Taylor, P., Hyman, J., Scholarios, D., Marks, A., Watson, A., Gilbert, K., Gall, G. and Bunzel, D. (2007) The Meaning of Work in the New Economy, Basingstoke: Palgrave

Barnes, A. (2007) 'The construction of control: the physical environment and the development of resistance and accommodation within call centres', New Technology, Work and Employment, 22.3: 246-259

Batt, R., Doellgast, Kwon, H., Nopany, M, Nopany, P. and da Costa, A. (2005) The Indian Call Centre Industry, Ithaca: Cornell University

Bhattacharjee, D. (2001) Organize. Labour and Economic Liberalization: Past, Present and Future, Geneva: ILO International Institute for labour Studies

Budhwar, P., Varmam A., Singh, V. and Dhar, R. (2006) 'HRM systems of Indian call centres: an exploratory study', International Journal of Human Resource Management, 17.5:881-897

Castree, N., Coe, N., Ward, K. and Samers, M. (2004) Spaces of Work, London: Sage

Chakrabarty, S. (2006) Making Sense of the Sourcing and Shoring Maze: Various Outsourcing and Offshoring Alternatives, in Outsourcing and Offshoring in the 21st century, H. Kehal and V. Singh, (eds), Idea Group Publishing, London, pp. 18-53.

Cohen, L. and El-Sawad, A. (2007) "Accounting for "us" and "them": Indian and UK customer service workers' reflections on offshoring', Economic and Political Weekly, 26/05/07:1951-1957

Cooke, M. (2005) Stretched to the Limits - CBPOP, BPOX and Call Centre Unionisation in India, London:Amicus

d'Cruz, P. and Noronha, E. (2006) 'Being professional: organizational control in Indian call centres', Social Science Computer Review, 24.2:342-361

Datta Chaudri, M. (1996) Labour Markets as Social Institutions in India, IRIS India Working Paper no. 10, College Park: MD

Dossani, R. and Kenney, M. (2006) Went for Cost, Stayed for Quality?: Moving the Back Office to India, Berkeley Roundtable on the International Economy, Working Paper Series no.1020 
Ellis, V. and Taylor, P. (2006) 'You don't know what you've got till it's gone: re-contextualising the origins, development and impact of the call centre', New Technology, Work and Employment, 21.2:107-

Fisher, M. (2004) 'The crisis of civil service trade unionism: a case study of call centre development', Work, Employment and Society, 18.1:157-177

Gall, G. (2005) 'Organizing non-union workers as trade unionists in the 'new economy' in Britain', Economic and Industrial Democracy, 26.1:41-63

Glucksmann, M. (2004) 'Call configurations: varieties of call centre and divisions of labour', Work, Employment and Society, 18.4:795-811

GOI (2002) Trade Union Verification Data, 1989 and 2002, New Delhi: Ministry of Labour, Government of India

GOI (2008a) Economic Survey 2006-7, retrieved 30 October 2008 from http://indiabudget.nic.in/es2006-07/social.htm

Green, F. (1990) 'Trade union availability and trade union membership in Britain', Manchester School of Economic and Social Studies, 58.4:378-394

Heery, E., Simms, M., Simpson, D., Delbridge, R. and Salmon, J. (2000) 'Organising unionism comes to the UK', Employee Relations, 22.1:38-57

Hirschfeld, K. (2005) IT Professionals Forums in India, Nyon: UNI

Karnik, V.B. (1978) Indian Trade Unions: a Survey, Bombay: Popular Prakashan

Kelley, P.F. (2002) 'Space of labour control: comparative perspectives from Southeast Asia', Transactions of the Institute of British Geographers, 27: 395-411

Kelly, J. (1998) Rethinking Industrial Relations, Routledge: London Kennedy, V.D. (1966) Unions, Employers and Government, Bombay: Manaktalas

Knights, D. and McCabe, D. (1998) 'What happens when the phone goes wild?: staff, stress and spaces for escape in a BPR regime', Journal of Management Studies, 35.2: 163-94. 
Kuruvilla, S., Das, S., Kwon, H. and Kwon, S. (2002) 'Trade Union Growth and Decline in Asia', British Industrial of Industrial Relations, 40.3: 431-461

Kuruvilla, S., Frenkel, S. and Peetz, D. (2003) 'MNCs as diffusers of best practice in HRM/IR in developing countries', in W. Cooke (ed.) Multinational Companies and Global Human Resource Strategies, Westport:Qurom

Legge, K. (2004) Human Resource Management: Rhetorics and Realities, Basingstoke: Palgrave McAdam, D. (1988) "Micromobilization contexts and recruitment to activism", International Social Movement Research, 1:125-54

McMillin, D. (2006) Outsourcing identities: call centres and cultural transformations in India', Economic and Political Weekly, 21/01/06:235-241

Miozzo, M. and Soete, L. (2001) 'Internationalization of services: a technological perspective', Technological Forecasting and Social Change, 67:159-185

Mirchandani, K. (2004) 'Practices of global capital: gaps, cracks and ironies in transnational call centres in India', Global Networks, 4.4:355-373

Nasscom (2002-2007) Strategy Review 2007: the IT Industry in India, New Delhi

Nasscom (2008) BPO Strategy Summit 2008, Conference Guide, Reference Resource Articles, New Delhi

Nasscom-McKinsey (2005) Extending India's Leadership of the Global IT and BPO Industries, New Delhi: Nasscom-McKinsey

Noronha, E. (1996) 'Liberalisation and industrial relations', Economic and Political Weekly, 31.8: L14-L20

Noronha, E. and d'Cruz, P. (2006) 'Organising call centre agents: emerging issues', Economic and Political Weekly, 27/05/06:2115-2121

Ofresno, R.E., Ng, C. and Marasigan-Pasumbal, L. (2007) 'Voice for the voice workers: addressing the IR concerns in the call centre/BPO industry of Asia', The Indian Journal of Industrial Relations, 42.4:534-557 
Peetz, D. (2002) 'Decollectivist strategies in Oceania', Relations Industrielles/Industrial Relations, $57.2: 252-281$

Poster, W.P. (2007) 'Who's on the line? Indian call centre agents pose as Americans for US outsourced firms', Industrial Relations, 46.2:492-497

Rainnie, A., Herod, A. and McGrath Champ, S. (2007) 'Spatialising industrial relations', Industrial Relations Journal, 38.2:102-118

Ramesh, B.P. (2005) Labour in Business Process Outsourcing: a Case Study of Call Centre, V.V.Giri National Labour Institute, Noida

Russell, R. (2007) 'You gotta lie to it: software applications and the management of technological change in a call centre', New Technology, Work and Employment, 22.2: 132-145

Sandhu, A. (2006) 'Why unions fail in organising India's BPO-ITES industry', Economic and Political Weekly, 14/10/06:4319-4322

Sheth, N. R. (1993). 'Our trade unions: An overview', Economic and Political Weekly, 27.6: 231236.

Simms. M. (2007) 'Interest formation in greenfield union organising campaigns', Industrial Relations Journal, 38.5:439-454

Taylor, P. and Bain, P. (2001) 'Trade unions, worker rights and the frontier of control in UK call centres', Economic and Industrial Democracy, 22:39-66

Taylor, P. and Bain, P. (2003a) Call Centres in Scotland and Outsourced Competition from India, Stirling:Scotecon

Taylor, P. and Bain, P. (2003b) 'Call centre organising in adversity: from Excell to Vertex', in G. Gall (ed.) Union Organising, London: Routledge: 153-172

Taylor, P. and Bain, P. (2005) "'India calling to the faraway towns": the call centre labour process and globalisation'. Work, Employment and Society, 19.2:261-282

Taylor, P. and Bain, P. (2006a) 'Work organisation and employee relations in Indian call centres', in J. Burgess and J. Connell (eds) Developments in the Call Centre Industry, London: Routledge, $36-57$ 
Taylor, P. and Bain, P. (2006b) An Investigation into the Offshoring of Financial Services Business Processes, Glasgow: Scottish Enterprise

Taylor, P. and Bain, P. (2007) 'Reflections on the call centre - a reply to Glucksmann', Work Employment and Society, 21.2:349-362

Taylor, P. and Bain, P. (2008) 'United by a common language?: Trade union responses in the UK and India to call centre offshoring', Antipode, 40.1:131-155

UNITES (2006) Review of UNITES@One, Bangalore: UNITES

Waddington, J. and Whitston, C. (1997) 'Why do people join unions in a period of membership decline?', British Journal of Industrial Relations, 35.4:515-546.

http://sify.com/news info/news/othernews/fullstory.php?id=14538595 Accessed 05/03/08 
Sample characteristics

\begin{tabular}{|c|c|c|c|c|}
\hline & $\begin{array}{c}\text { All } \\
(N=879)\end{array}$ & $\begin{array}{l}\text { Captive } \\
(N=192)\end{array}$ & $\begin{array}{c}\text { Indian } 3^{\text {rd }} \\
\text { party } \\
(N=69)\end{array}$ & $\begin{array}{c}\text { Domestic } \\
(N=618)\end{array}$ \\
\hline & $\%$ & $\%$ & $\%$ & $\%$ \\
\hline Joined UNITES in last year & 69 & 49 & 28 & 80 \\
\hline Joined UNITES $>1$ year ago & 31 & 51 & 72 & 20 \\
\hline Male & 52 & 58 & 66 & 48 \\
\hline Female & 48 & 42 & 34 & 52 \\
\hline Full-time & 92 & 100 & 85 & 90 \\
\hline Part-time & 8 & 0 & 15 & 10 \\
\hline Call centre/BPO work & 40 & 67 & 28 & 33 \\
\hline Call centre work only & 60 & 33 & 72 & 67 \\
\hline Inbound calls & 71 & 77 & 83 & 69 \\
\hline Outbound calls & 29 & 23 & 18 & 31 \\
\hline \multicolumn{5}{|l|}{ Career intentions } \\
\hline Long-term job & 24 & 39 & 41 & 18 \\
\hline Career in this company & 25 & 25 & 30 & 26 \\
\hline Career in BPO industry & 44 & 30 & 22 & 52 \\
\hline Career outside BPO & 5 & 10 & 8 & 3 \\
\hline \multirow[t]{2}{*}{ Not part of career } & 6 & 7 & 18 & 5 \\
\hline & Mean & Mean & Mean & Mean \\
\hline Age & 24.3 & 27.0 & 25.6 & 23.4 \\
\hline Tenure (months) & 17.4 & 25.9 & 29.5 & 13.4 \\
\hline Monthly contracted hours ${ }^{\text {a }}$ & 216 & 206 & 191 & 219 \\
\hline
\end{tabular}

Note: ${ }^{a}$ Based on restricted sample range $(79 \%)$ who provided calculable responses. 
Table 2: Reasons for joining UNITES (\%)

\begin{tabular}{|c|c|c|c|c|c|c|c|c|}
\hline & All & Captive & $\begin{array}{c}3^{r d} \\
\text { party }\end{array}$ & Dom. & Men & Women & $\begin{array}{l}\text { Ten. } \\
<=1 \\
y r .\end{array}$ & $\begin{array}{l}\text { Ten } \\
>1 \\
y r\end{array}$ \\
\hline $\mathbf{N}$ & 879 & 192 & 69 & 618 & 448 & 417 & 495 & 376 \\
\hline \multicolumn{9}{|l|}{ Traditional collectivist } \\
\hline I believe in trade unions & 37.7 & 62.0 & 23.9 & 31.7 & 41.1 & 33.8 & 29.2 & 48.7 \\
\hline People with the same attitudes & 30.4 & 55.7 & 41.8 & 21.3 & 35.7 & 24.5 & 16.2 & 48.7 \\
\hline Other people at work members & 32.7 & 53.1 & 52.2 & 24.2 & 34.8 & 28.8 & 18.3 & 51.1 \\
\hline $\begin{array}{l}\text { BPO professionals should have } \\
\text { independent representation }\end{array}$ & 27.4 & 52.6 & 41.8 & 18.0 & 30.6 & 23.5 & 16.8 & 40.9 \\
\hline \multicolumn{9}{|l|}{ Collectivist/social } \\
\hline Gave support for a problem & 24.7 & 56.8 & 58.2 & 11.0 & 28.8 & 19.9 & 4.5 & 50.3 \\
\hline Activities help the community & 23.1 & 69.8 & 23.9 & 8.4 & 24.0 & 21.8 & 9.5 & 40.4 \\
\hline Campaigns to improve conditions & 21.5 & 52.6 & 37.3 & 10.1 & 26.1 & 16.5 & 4.7 & 43.3 \\
\hline Provides housing/welfare info. & 18.4 & 52.1 & 28.4 & 6.8 & 22.7 & 13.9 & 4.3 & 36.6 \\
\hline Provides social activities/fun & 15.0 & 48.4 & 20.9 & 3.9 & 17.1 & 12.9 & 2.8 & 30.5 \\
\hline \multicolumn{9}{|l|}{ Instrumental (individualist/collectivist) } \\
\hline Will improve my pay \& conditions & 74.7 & 80.7 & 40.3 & 76.6 & 74.2 & 75.5 & 84.0 & 62.6 \\
\hline Information/advice about rights & 64.6 & 69.3 & 37.3 & 66.1 & 64.3 & 65.2 & 71.2 & 55.9 \\
\hline \multicolumn{9}{|l|}{ Careerist/instrumental } \\
\hline Will help in my career & 36.5 & 50.0 & 26.9 & 33.3 & 38.9 & 33.6 & 32.0 & 42.0 \\
\hline $\begin{array}{l}\text { Provides training which will } \\
\text { enhance skills/knowledge }\end{array}$ & 29.0 & 52.1 & 28.4 & 21.9 & 33.3 & 24.2 & 20.7 & 39.8 \\
\hline
\end{tabular}


Table 3: Reasons prompting colleagues to join UNITES

\begin{tabular}{|c|c|c|c|c|c|c|c|c|c|}
\hline & All & All & Captive & $\begin{array}{c}3^{r d} \\
\text { party }\end{array}$ & Dom. & Men & Women & $\begin{array}{l}\text { Ten. } \\
<= \\
\text { lyr. }\end{array}$ & $\begin{array}{l}\text { Ten. } \\
>1 \\
y r .\end{array}$ \\
\hline & $\begin{array}{c}\% \\
\text { v.imp }\end{array}$ & \multicolumn{8}{|c|}{ Importance ratios $^{a}$} \\
\hline Working times & 64.5 & 94.7 & 96.8 & 84.6 & 95.1 & 95.9 & 93.3 & 94.3 & 95.1 \\
\hline $\mathrm{H} \& \mathrm{~S}$ issues & 45.4 & 93.2 & 89.2 & 78.5 & 96.1 & 92.2 & 94.2 & 99.2 & 85.1 \\
\hline Security eg transport & 63.8 & 93.2 & 90.4 & 74.6 & 96.0 & 92.5 & 94.2 & 97.5 & 87.3 \\
\hline Pressure of work & 39.6 & 93.1 & 93.6 & 81.5 & 94.1 & 94.5 & 91.3 & 95.1 & 90.2 \\
\hline Targets & 44.5 & 89.8 & 78.6 & 80.6 & 94.1 & 88.9 & 91.3 & 97.5 & 79.2 \\
\hline Need for employee voice & 59.0 & 87.1 & 78.1 & 74.6 & 91.1 & 85.9 & 88.3 & 96.3 & 75.0 \\
\hline Job insecurity & 61.7 & 87.0 & 63.2 & 60.0 & 97.0 & 85.3 & 89.3 & 93.9 & 77.3 \\
\hline Pay & 46.3 & 78.1 & 59.1 & 60.0 & 85.6 & 78.7 & 77.2 & 85.4 & 67.7 \\
\hline Demanding supervisor & 29.2 & 76.1 & 55.2 & 55.6 & 84.6 & 73.3 & 80.3 & 87.7 & 59.9 \\
\hline Bonuses/benefits & 37.0 & 74.9 & 47.6 & 50.8 & 85.9 & 70.6 & 81.1 & 88.6 & 56.0 \\
\hline Travel to work times & 47.0 & 56.5 & 69.9 & 59.4 & 52.1 & 55.2 & 60.4 & 64.4 & 45.6 \\
\hline Mgt. goes back on promises & 36.7 & 51.2 & 59.4 & 53.1 & 48.4 & 57.7 & 44.2 & 45.6 & 58.7 \\
\hline 'Apple polishing' & 22.4 & 25.2 & 35.2 & 58.7 & 18.7 & 23.2 & 28.5 & 13.0 & 41.5 \\
\hline Difficult to leave (employers) & 17.2 & 22.8 & 40.9 & 43.8 & 15.0 & 26.5 & 20.4 & 8.6 & 41.1 \\
\hline Abusive customers & 13.0 & 8.1 & 32.6 & 53.8 & -3.9 & 9.3 & 7.9 & 11.3 & 33.5 \\
\hline
\end{tabular}

Notes. Reasons ranked by overall importance ratio.

a Importance ratios are calculated by subtracting percentages answering 'not at all' or 'somewhat' important from percentages answering 'quite' or 'very' important. High positive values represent consistently high importance; lower scores indicate divided views; and negative scores indicate greater agreement that the issue was not important. 
Table 4: Role of $H R$

\begin{tabular}{|c|c|c|c|c|c|c|}
\hline & \multicolumn{2}{|c|}{$\begin{array}{l}\text { HR presence } \\
\text { removes the } \\
\text { need for trade } \\
\text { unions }\end{array}$} & \multicolumn{2}{|c|}{$\begin{array}{c}\text { I turned to HR } \\
\text { to get } \\
\text { problems } \\
\text { resolved } \\
\end{array}$} & \multirow{3}{*}{$\begin{array}{c}\text { HR's success } \\
\text { at listening to/ } \\
\text { understanding } \\
\text { problems }^{a} \\
\qquad \%\end{array}$} & \multirow{3}{*}{$\begin{array}{c}\text { HR's success } \\
\text { at taking } \\
\text { action to solve } \\
\text { problems }^{a} \\
\%\end{array}$} \\
\hline & & $\%$ & & $\%$ & & \\
\hline & $N$ & Yes & $N$ & Yes & & \\
\hline \multicolumn{7}{|l|}{ Industry } \\
\hline Captive & 174 & 28.2 & 75 & 42.6 & 54.5 & 39.8 \\
\hline Indian 3rd party & 63 & 44.4 & 20 & 31.7 & 66.3 & 59.0 \\
\hline Domestic & 609 & 10.0 & 89 & 15.1 & 18.9 & 7.4 \\
\hline \multicolumn{7}{|l|}{ Respondent } \\
\hline Male & 428 & 19.9 & 90 & 21.6 & 28.3 & 18.9 \\
\hline Female & 407 & 12.8 & 91 & 22.8 & 26.3 & 12.2 \\
\hline Tenure $<=1$ year & 490 & 6.5 & 77 & 16.3 & 15.2 & 4.9 \\
\hline Tenure $>1$ year & 352 & 29.5 & 104 & 29.7 & 48.0 & 34.3 \\
\hline Not a career & 95 & 24.2 & 26 & 26.8 & 41.7 & 27.8 \\
\hline Want career in BPO & 366 & 5.5 & 43 & 11.7 & 5.7 & 3.2 \\
\hline Want company career & 385 & 24.4 & 115 & 31.7 & 46.5 & 25.7 \\
\hline Total sample & 846 & 16.2 & 184 & 22.2 & 27.3 & 15.4 \\
\hline
\end{tabular}

Note. ${ }^{\text {a }}$ Based on 184 respondents who reported turning to HR to resolve problems 


\begin{tabular}{|c|c|c|c|c|c|c|c|c|c|}
\hline & All & All & Captive & $\begin{array}{c}3^{r d} \\
\text { party }\end{array}$ & Dom. & Men & Women & $\begin{array}{l}\text { Ten. } \\
<=1 \\
y r\end{array}$ & $\begin{array}{c}\text { Ten. } \\
>1 \\
y r\end{array}$ \\
\hline & $\begin{array}{c}\% \\
\text { v.imp }\end{array}$ & \multicolumn{8}{|c|}{ Importance ratios $^{a}$} \\
\hline $\begin{array}{l}\text { High attrition: hard to recruit } \\
\text { and build stable membership }\end{array}$ & 47.9 & 83.3 & 66.7 & 51.5 & 91.8 & 82.7 & 83.4 & 95.5 & 66.9 \\
\hline $\begin{array}{l}\text { BPO employees see } \\
\text { themselves as professionals }\end{array}$ & 54.3 & 77.7 & 67.9 & 75.8 & 81.0 & 79.6 & 76.5 & 88.1 & 63.7 \\
\hline $\begin{array}{l}\text { High salaries mean } \\
\text { employees don't need to join }\end{array}$ & 57.0 & 71.4 & 82.7 & 39.4 & 71.4 & 73.1 & 70.2 & 79.5 & 60.8 \\
\hline $\begin{array}{l}\text { Many BPO professionals } \\
\text { think they will be promoted }\end{array}$ & 33.8 & 70.5 & 49.5 & 36.4 & 80.5 & 72.4 & 69.0 & 83.6 & 52.2 \\
\hline $\begin{array}{l}\text { Employees think joining will } \\
\text { affect their careers }\end{array}$ & 45.2 & 68.7 & 20.7 & 57.6 & 84.2 & 66.7 & 69.8 & 75.7 & 58.7 \\
\hline $\begin{array}{l}\text { Fear companies terminate } \\
\text { someone for joining }\end{array}$ & 54.1 & 65.0 & 76.3 & 41.5 & 64.2 & 66.2 & 64.1 & 71.1 & 56.3 \\
\hline $\begin{array}{l}\text { Many BPO employees do not } \\
\text { believe in trade unions }\end{array}$ & 47.3 & 61.1 & 46.7 & 46.9 & 66.9 & 61.2 & 62.3 & 69.7 & 50.0 \\
\hline $\begin{array}{l}\text { Companies are opposed to } \\
\text { UNITES }\end{array}$ & 56.7 & 57.3 & 70.5 & 49.2 & 53.9 & 59.7 & 58.2 & 61.0 & 53.1 \\
\hline $\begin{array}{l}\text { Workforce is young and } \\
\text { inexperienced }\end{array}$ & 53.1 & 56.9 & 73.0 & 45.5 & 53.5 & 55.7 & 61.8 & 63.1 & 49.6 \\
\hline $\begin{array}{l}\text { Employees believe problems } \\
\text { will be solved by managers }\end{array}$ & 32.6 & 53.4 & 64.8 & 39.4 & 51.5 & 56.5 & 50.0 & 46.8 & 62.0 \\
\hline $\begin{array}{l}\text { Many BPO professionals do } \\
\text { not see the need for UNITES }\end{array}$ & 37.4 & 48.6 & 47.3 & 36.4 & 50.3 & 45.8 & 54.7 & 62.2 & 31.7 \\
\hline $\begin{array}{l}\text { Employees believe the } \\
\text { employer is all they need }\end{array}$ & 37.8 & 36.3 & 65.2 & 23.1 & 28.9 & 36.1 & 36.5 & 30.5 & 43.6 \\
\hline $\begin{array}{l}\text { Unions in BPO are seen as } \\
\text { damaging to industry growth }\end{array}$ & 25.7 & 17.9 & -33.3 & 44.6 & 29.7 & 24.2 & 9.5 & 6.0 & 34.5 \\
\hline $\begin{array}{l}\text { Employers have captured } \\
\text { employees' hearts and minds }\end{array}$ & 14.3 & -13.1 & 23.2 & 35.4 & -29.4 & -4.1 & -22.0 & -47.0 & 31.3 \\
\hline
\end{tabular}

Notes. Reasons ranked by overall importance ratio for sample. ${ }^{\text {a }}$ Importance ratios calculated as for Table 3 


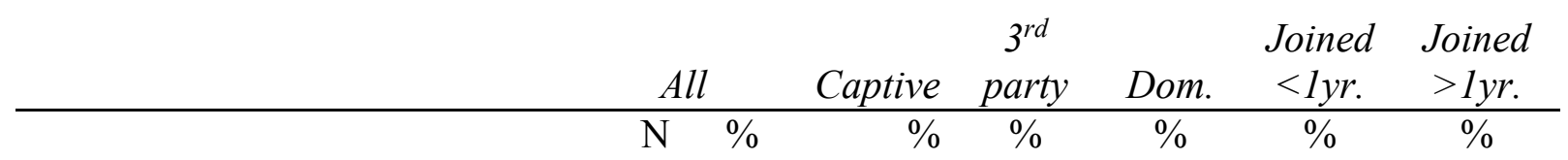

How did you find out about UNITES?

$\begin{array}{lrrrrrrr}\text { Colleague/friend: at work } & 645 & 74.3 & 78.6 & 62.3 & 73.1 & 82.9 & 60.2 \\ \text { UNITES website } & 234 & 26.7 & 5.2 & 18.8 & 34.2 & 32.4 & 15.7 \\ \text { Friend/relative: other cc/BPO } & 156 & 17.8 & 27.1 & 44.9 & 11.8 & 8.6 & 34.9 \\ \text { UNITES leaflet/poster } & 91 & 10.4 & 3.6 & 23.1 & 11.1 & 9.4 & 13.2 \\ \text { UNITES campaign/meeting } & 41 & 4.7 & 3.6 & 8.7 & 4.5 & 3.2 & 8.4\end{array}$

How did you join UNITES? ${ }^{a}$

Member in workplace

Colleagues in workplace

Friend/relative

Team leader/manager $\begin{array}{ll}700 & 80.3\end{array}$

19222

$98 \quad 11.2$

$\begin{array}{ll}68 & 7.8\end{array}$
67.2

47.1

27.0

51.5

4.8

14.7

$\begin{array}{lll}0 & 16.2 \quad 9.3\end{array}$

5.8
60.1

36.3

13.3

8.1

Notes. ${ }^{\text {a }}$ Table shows the most popular of 11 options 